\title{
AGAMA, MODAL SOSIAL DAN KETAHANAN MASYARAKAT DALAM MENGHADAPI BENCANA DI KOTA BANDA ACEH
}

\author{
Fajri M Kasim ( $\left.{ }^{*}\right)$, Abidin Nurdin ( $\left.{ }^{2}\right)$, M. Rizwan ( $\left.{ }^{\beta}\right)$, \\ 123 Faculty of Social and Political Sciences, Universitas Malikussaleh, Aceh, Indonesia.
}

\begin{tabular}{ll} 
ARTICLE INFORMATION \\
\hline $\begin{array}{ll}\text { Submitted } & : 29^{\text {th }} \text { November, } 2020 \\
\text { Review } & : 15^{\text {th }} \text { April, } 2021 \\
\text { Accepted } & : 21^{\text {st }} \text { May, } 2021 \\
\text { Published } & : 07^{\text {th }} \text { June, } 2021 \\
\text { Available Online } & : \text { June, } 2021\end{array}$ \\
\begin{tabular}{l} 
KEYWORDS \\
\hline Religion; social capital; norms and values; \\
socialization of values and disaster resilience. \\
CORRESPONDENCE \\
\hline *E-mail: fajri@unimal.ac.id \\
fajrimkasim@gmail.com
\end{tabular} \\
\hline
\end{tabular}

\begin{abstract}
A B S T R A C T
This article examines religion as social capital in realizing resilience in Aceh. The purpose of this research is to discuss how religion and its values become social capital, and how to socialize these religious values in society. This research is a qualitative research procedure that produces descriptive data in the form of written or spoken words from observable people's behavior. The theory used is social capital which believes that religious values, norms and beliefs contained in social structures and structures are able to bond and integrate society to move together to solve problems. The approach is ethnography, which is a written description of people's way of life. There are three data techniques, namely; interviews, observation and document study, then analyzed by exclusion, namely matching all data that has been obtained. The results showed that religion is capable of being a social capital, as well as having values and the norms of tawhid, patience, sincerity, tawakkal and togetherness; These values and norms have been socialized since Islam entered Aceh and continue to be carried out by families and religious leaders through education. Thus, through religion as social capital, it can create resilience in the face of disasters in Acehnese society.
\end{abstract}

\section{A. PENDAhULUAN}

$\mathrm{S}$ ecara geologi Indonesia berada di atas lintas tiga lempeng tektonik yang besar, yaitu IndoAustralia, Eurasia dan lempeng Pasifik. Zona pertemuan antara lempeng Indo-Australia dengan lempeng Eurasia di lepas pantai barat Sumatera, selatan Jawa dan Nusa Tenggara, sedangkan dengan lempeng Pasifik di bagian utara pulau Papua dan Halmahera. Zona ini umumnya juga ditandai dengan keberadaan palung yang cukup dalam. Sementara itu deret gunung api merupakan bagian dari Asia-Pasifik yang sering disebut sebagai cincin api (BNPB, 2016, Putri dan Azwar, 2020).

Realitas geologis tersebut mengakibatkan Indonesia akan selalu diancam oleh gempa bumi yang dapat mengakibatkan tsunami. Gempa dan tsunami yang paling dahsyat terjadi pada 26 Desember 2004 yang berkekuatan berkekuatan 8,9 skala richter telah memporak-porandakan seluruh sendi kehidupan masyarakat Aceh. Akibatnya tercatat 110.299 orang yang meninggal, 12.132 orang yang hilang dan 703.518 orang kehilangan tempat tinggal (BRR NAD-NIAS,
2005). Demikian juga kerugian secara ekonomi sekitar 45000 juta Dollar Amerika, (BNPB, 2016: 56).

Jika merujuk pada laporan Badan Penanggulangan Bencana Indonesia (BNBP) bahwa ada 10 jenis bencana yang dapat membahayakan jiwa manusia yaitu; gempa bumi, tsunami, letusan gunung berapi, banjir, longsor, kekeringan, kebakaran lahan dan hutan, cuaca ekstrim, gelombang ekstrim dan abrasi dan banjir bandang (BNPB, 2016: 122).

BNBP dalam desain pengurangan risiko bencana alam di Indonesia menjadikan agama dan sikap hidup sebagai unsur yang penting dalam penanggulangan bencana sehingga tokoh agama selalu dihadirkan (BNPB, 2016: 122). Pihak BNPB menyadari bahwa agama sebagai sumber modal sosial dapat membentuk ketahanan masyarakat terhadap bencana dan mengurangi risiko bencana. Penggunaan agama dan kearifan lokal juga dipakai oleh masyarakat Bali yang mayoritas beragama Hindu. Menurut Paramita (2018: 36) bahwa masyarakat Bali menyakini bahwa antara bhuana agung dan bhuana alit memiliki hubungan 
kosmis yang integralistik. Karena itu, segala aktivitas kehidupan dan ritual umat Hindu senantiasa memuliakan dan menjaga kosmik yang didasarkan pada kesadaran manusia terpusat pada alam (kosmos).

Penggunaan agama dan kearifan lokal sebagai modal sosial dalam menghadapi bencana juga dilakukan India dan Malaysia. Marfai (2016) mengkaji tentang peran kearifan lokal dan modal sosial dalam pengurangan risiko bencana dan pembangunan pesisir di India dan Indonesia. Kajian ini menyimpulkan bahwa kearifan lokal menjadi modal sosial yang ampuh dalam mengurasi resiko bencana. Amir Zal (2018) menulis tentang ketahanan komunitas korban bencana banjir di pantai timur semenanjung Malaysia. la menyimpulkan bahwa modal sosial mampu memberikan sumbangan kepada peningkatan pengetahuan, hubungan antara komunitas, elemen pendapatan dan aset, ketersediaan kemudahan asas dan pengetahuan, pergantungan dan pengamalan agama responden.

Aceh sebagai daerah yang pernah menjadi episentrum gempa, sebenarnya memiliki modal sosial berupa norma-norma lokal dapat dilacak di Simeulu yang dikenal dengan nama smong. Smong tersebut terbukti menyelamatkan ratusan nyawa ketika terjadi tsunami tahun 1907 dan 2004 yang berbatasan langsung dengan lautan Hindia (Sari, Husin dan Syamsidik, 2018: 1).

Sebagaimana smong, nilai-nilai agama di Banda Aceh terbukti memberikan pondasi yang kuat dalam membentuk ketahanan jiwa menghadapi bencana. Suwignyo (2019) menegaskan bahwa masyarakat yang kehilangan harta benda dan keluarga setelah selamat dari tsunami memiliki kepercayaan agama dan membantu untuk melalui masa sulit.

Keberhasilan modal sosial sebagai senjata dalam menghadapi sesuatu yang membahayakan manusia juga terbukti berhasil digunakan oleh masyarakat Ujoeng Pacu, Lhokseumawe, Aceh dalam melawan mafia narkoba. Modal sosial keagamaan menjadi semen perekat yang menyatukan masyarakat dalam memberantas barang haram tersebut (Nirzalin dan Febriandi, 2020: 210).

Modal sosial yang terdiri dari norma, jaringan dan hubungan saling percaya yang melahirkan kolektivitas (Chassidy dan Narayan: 2000: 1187-1193). Normanorma atau nilai-nilai yang dapat berasal dari agama dan tatanan sosial budaya. Pada konteks masyarakat Aceh norma dan nilai-nilai dominan berasal dari agama yaitu Islam (Kasim dan Nurdin, 2016, 2020). Sedangkan ketahanan bencana adalah kapasitas sebuah komunitas atau masyarakat yang memiliki potensi terpapar bencana untuk beradaptasi dengan cara bertahan yang berasal dari sistem sosial masyarakat (UNISDR, 2004; 2011).

Hal tersebut dapat terjadi karena agama yang memiliki seperangkat nilai bagi manusia dalam menghadapi kehidupan, baik untuk hal yang bersifat individu maupun sosial, justru sering diabaikan dan diacuhkan keberadaannya. Sejatinya, agama manapun, termasuk Islam mustahil mengajarkan sesuatu hal yang bersifat amoral, terlebih apabila hal tersebut berdampak negatif tidak hanya bagi manusia itu sendiri melainkan meluas hingga kepada seluruh makhluk hidup, bahkan alam (Sukmana, 2013: 4).

Oleh karena itu kajian ini akan membahas tentang agama, nilai dan norma agama serta bagaimana sosialisasinya dalam masyarakat sehingga mampu menjadi modal sosial dalam mewujudkan ketahanan bencana di Kota Banda Aceh. Kajian ini penting untuk dilakukan untuk menjelaskan bagaimana agama serta norma dan nilainya mampu menjadi modal sosial dalam menghadapi bencana terutama gempa dan tsunami.

\section{B. METODE PENELITIAN}

$\mathrm{K}$ ajian ini menggunakan penelitian ini kualitatif (kualitatif approch). Bogdan dan Taylor sebagaimana disebutkan oleh Moleong (1997: 3) dan Denzin \& Yvonna (2009: 5) mengatakan bahwa penelitian kualitatif sebagai prosedur penelitian yang menghasilkan data deskriptif berupa kata-kata yang tertulis atau lisan dari orang-orang dan prilaku yang dapat diamati. Teori yang digunakan adalah modal sosial, menurut Putman, (2004: 6) modal sosial terdiri dari dua macam yaitu modal sosial kognitif dan struktural. Modal sosial kognitif yang terdiri dari nilainilai, nilai-nilai dan perilaku yang melahirkan rasa percaya antar anggota masyarakat dalam hubungan sosial mereka. Kemudian modal social structural adalah pelbagai aktivitas, struktur organisasi dan prinsip-prinsip demokratis yang mendukung tindakatan kolektif dan dalam pengambilan keputusan (Fukuyama, 1999: 2-3).

Ritzer, (2004) menjelaskan bahwa modal sosial merujuk pada kapasitas individu untuk memperolah barang material atau simbol yang bernilai berdasarkan kebajikan hubungan sosial dan keanggotaan dalam kelompok sosial atau kapasitas pluralitas seseorang untuk menikmati keuntungan dari tindakan kolektif berdasarkan kebajikan dari partisitasi sosial, kepercayaan terhadap institusi dan komitmen untuk menetapkan cara dalam melakukan sesuatu.

Menurut Darmi (2016: 25) modal sosial adalah seperangkat daya dalam membangun hubunganhubungan sosial, jaringan, membentuk komunitas dan organisasi yang dapat dipergunakan untuk mengatasi masalah yang dihadapi. Karena itu, modal sosial tidak hanya melihat hasil akan tetapi lebih mementingkan proses. Modal sosial bertumpu pada gagasan kepercayaan, norma dan jaringan informal dan percaya bahwa relasi sosial adalah sumber daya yang berharga (Fathy, 2019: 3).

Jadi dengan demikian inti dari modal sosial adalah norma atau nilai, jaringan dan hubungan kepercayan. Pada konteks penelitian modal sosial yang dielaborasi adalah norma dan nilai yang terdapat dalam struktur dan tatanan sosial masyarakat. Norma dan nilai tersebut adalah agama yang dianut secara fanatik dan mayoritas dalam masyarakat Aceh. Teori modal sosial inilah yang akan dijadikan sebagai pisau analisis dalam mengkaji relasi antara agama dan ketahanan bencana dalam masyarakat Aceh.

Sedangkan pendekatan yang digunakan adalah etnografi yang biasa digunakan dalam penelitian sosial. Etnografi yaitu deskripsi tertulis mengenai organisasi 
sosial, aktivitas sosial, simbol dan materi serta karakteristik praktik interpretasi suatu kelompok. Etnografi juga merupakan penelitian tentang the way of life masyarakat (Duranti, 1997).

Lokasi penelitian difokuskan pada masyarakat Banda Aceh dengan alasan bahwa wilayah ini merupakan daerah yang terdampak cukup parah ketika terjadi gempa dan tsunami 2004, baik secara fisik maupun psikis. Teknik pengumpulan data menggunakan tiga yaitu; wawancara mendalam, studi literatur dan observasi.

\section{HASIL DAN PEMBAHASAN}

\section{Agama sebagai Modal Sosial dalam Menghadapi Bencana}

A gama dapat menjadi modal sosial masyarakat Aceh dalam mewujudkan ketahanan bencana Imenurut Tu Bulqani Tanjongan, Wakil Ketua Majelis Permusyawaratan Ulama Kota Banda Aceh karena keyakinan tauhid kepada Allah yang sangat kuat. Jika tauhid dan aqidah sudah mengakar dalam jiwa orang Aceh, maka apapun akan dilakukan, jangankan harta, nyawa pun akan dikorbankan, hal ini sudah dicatat dalam sejarah. Ketika Aceh melawan Belanda, senjata, dan meriam ketika terdengar bukan lari justru mencari darimana sumber meriam itu lalu kemudian mereka membunuh Belanda. Orang Aceh berkeyakinan bahwa yang wafat dalam peperangan melawan kafir Belanda dianggap syahid. Ketika syahid maka orang yang termasuk keluarganya tidak akan memberikan efek sedih apalagi stress, justru mereka bangga dan bahagia, karena balasan syahid adalah syurga dari Allah (Wawancara, 23 September 2020).

Sejalan dengan itu, Dr. Mursyid Djawas (salah seorang dosen UIN Ar-Raniry) menegaskan bahwa agama menjadi modal sosial yang utama bagi masyarakat Aceh dalam menghadapi bencana termasuk gempa dan tsunami. Sejarah membuktikan bahwa masyarakat Aceh sepanjang puluhan tahun dilanda konflik pada saat melakukan perlawanan terhadap penjajah dan modal utama mereka dalam perjuang adalah agama. Kemudian pada saat gempa dan tsunami mereka juga teruji ketahanannya secara psikologis. Jiwa orang Aceh kuat secara agama dan aqidah dalam menghadapi konflik melawan penjajah, konflik kemanusiaan selama lebih dari 30 tahun, apalagi bangkit pasca tsunami (Wawancara, 24 Oktober 2020).

Pandangan tersebut juga dikuatkan oleh Teungku Rusli Daud, MA (Ketua Nahdlatul Ulama, sekaligus Anggota MPU Kota Banda Aceh) bahwa agama dapat menjadi modal sosial masyarakat Aceh dalam menghadapi bencana disebabkan oleh dua hal; pertama, karena memang Aceh adalah wilayah yang diberkahi oleh Allah, dan Allah memuliakan orang Aceh. itu juga sebabnya mengapa orang Aceh disebut Serambi Mekkah, tidak hanya karena Aceh merupakan daerah yang pertama kali menerima Islam, kedua, karena kekuatan fisik orang Aceh yang secara fisik memang kuat terbukti dalam sepanjang sejarah Aceh dilanda konflik, bencana beberapa kali masyarakat
Aceh tetap kuat dalam mengahadapi musibah dan bencana tersebut. Di samping itu mental orang Aceh juga cukup kuat. Inilah yang menyebabkan perbedaan antara orang Aceh dengan wilayah lain di Indonesia (Wawancara, 22 September 2020).

Menurut NA salah seorang warga yang selamat dari gempa dan tsunami di Masjid Raya Baiturrahman ketika ia berlari dari toko tempat bekerja yang berjarak sekitar 200 meter bahwa ada sekitar 400 orang yang selamat di Masjid tersebut. Menurutnya ia berlari sekuat tenaga menuju masjid karena ia yakin bahwa masjid merupakan rumah Allah dan bangunan keagamaan yang suci yang dapat menjadi sebab selamat dari gelombang tsunami. Dengan kekuasaan Allah air tsunami tidak masuk ke dalam masjid melainkan hanya di samping dan pelatarannya saja. la berada di masjid selama kurang lebih satu jam ketika gelombang tsunami datang dengan kecepatan yang tidak terkira. Gelombang tsunami menerjang disertai dengan gempa susulan beberapa kali (Wawancara, 16 Oktober 2020).

Ada perbedaan mendasar antara korban konflik dan korban tsunami dilihat dari sisi agama dalam masyarakat. Korban konflik mereka anggap sebagai korban yang dilakukan oleh manusia, pembunuhan, penculikan, penganiayaan bahwa pemerkosaan adalah perbuatan dan dilakukan manusia. hal ini merupakan ketidak adilan yang menginjak-injak harga diri dan marwah orang Aceh. Sedangkan korban tsunami merupakan takdir dan iradah Allah yang secara aqidah wajib diimani dan diterima. Karena itu, sebodohbodohnya orang Aceh tidak akan pernah menyalahkan Allah, sebab itu kita tidak pernah mendengar orang Aceh menyalahkan Allah karena keluarga dan hartanya hilang gara-gara tsunami. Pada sisi yang sama, rasa balas dendam orang Aceh terhadap manusia sebagai makhluk yang berbuat zalim akan meunucul jika ia mengzalimi diri dan keluarganya, sebalik kepada Allah wajib taat dan berimana kepada takdir (Wawancara dengan Tu Bulqaini Tanjongan, 23 September 2020).

Agama mampu menjadi benteng jiwa dalam menghadapi bencana sedhasyat apa pun, bahkan dibandingkan dengan tsunami di Jepang. Yubahri, Sekretaris Badan Penanggulangan Bencana Daerah (BPBD) Kota Banda Aceh menceritakan bahwa orang Jepang datang ke Banda Aceh di Kantor BPBD yang terdiri dari mahasiswa dan dosen pada tahun 2014 dan 2015 mereka heran sambil bertanya mengapa orang Aceh begitu kuat menghadapi bencana. Saya jawab bahwa agama yang menyebabkan mereka kuat, keyakinan dalam terhadap takdir sebagai suatu ketentuan dari Allah yang wajib mereka terima dan ikuti. Terikat dengan itu, saya pernah mempresentasikan di Korea Selatan dan Tanzania sebuah Negara di Afrika tentang ketahanan masyarakat Aceh terhadap bencana, dan saya menegaskan bahwa kunci ketahanan orang Aceh ada pada agamanya. Ini adalah bukti bahwa Aceh dapat dijadikan sebagai wilayah contoh atau pelajaran yang dapat menjadi pilot projek sebagai Kota Ketahanan Bencana di Indonesia bahkan Dunia (Wawancara, 22 September 2020).

Oleh karena itu, berdasarkan beberapa argumentasi tersebut di atas, agama mampu menjadi 
modal sosial masyarakat Aceh dalam menghadapi bencana. Ketahanan dalam arti mereka memiliki mitigasi dan persiapan yang kuat terhadap bencana sehingga terjadi pengurangan korban jiwa atau harta; adanya kelenturan struktur sosial jika bencana terjadi yang berfungsi dan berjalan sebagaimana mestinya; kecepatan pemulihan dalam arti upaya untuk kembali ke kondisi normal tidak memerlukan waktu yang cukup lama.

\section{Nilai Agama yang Menjadi Modal Sosial dalam Menghadapi Bencana}

\section{a. Tauhid}

Tauhid merupakan norma dan nilai hal yang sangat menonjol dalam masyarakat Aceh. menurut Tu Bulqaini Tanjongan bahwa tauhid dan aqidah kepada Allah inilah yang terus terbangun dalam diri masyarakat Aceh dan ketika tsunami datang, keluarga mereka yang meninggal, harta yang hilang dianggap sebagai titipan dari Allah, sebab itu adalah semuanya mililik Allah. Inilah yang menjadi rahasia sehingga masyarakat Aceh tidak ada yang stress, gila apalagi bunuh diri saat tsunami. Jika ada yang stress dan gila itu boleh jadi korban konflik, masyarakat Aceh yang kehilangan keluarga saat konflik dan tsunami itu pengaruhnya berbeda seperti yang saya katakan sebelumnya. Sebab konflik yang membunuh adalah manusia itu yang mereka tidak terima, sedangkan tsunami itu adalah takdir dari Allah (Wawancara, 23 September 2020).

Tauhid yang kuat kepada Allah sebagai Tuhan Yang Maha Pengatur, menurut Mursyid Djawas merupakan soko guru yang membentengi masyarakat Aceh sehingga mampu bertahan bahkan bangkit dari terpaan bencana gempa dan tsunami. Karena itu kita tidak pernah melihat dan mendengar bahwa ada orang Aceh menderita gangguan jiwa bahkan bunuh diri karena keluarganya korban bencana atau hartanya habis. Mungkin ini yang membedakan antara karakter masyarakat Aceh dengan masyarakat yang lain di Indonesia atau di negara lain (Wawancara, 24 Oktober 2020).

Hal tersebut menunjukkan bahwa masyarakat Aceh memiliki tauhid dan aqidah yang kuat. Yaitu hubungan antara hamba dan Tuhan sebagai Yang Maha Pencipta dan Maha Kuasa atas segala sesuatu. Terbukti ketika dalam keadaan mendapat musibah dan bencana ingat kepada Allah tetap terpelihara, dalam bentuk zikir, berdoa, memuji Allah, membaca al-Quran.

\section{b. Sabar}

Sabar bermakna kokoh pendirian, gigih, ulet, tahan menderita, tanpa gelisah, tanpa keluh kesah. Karena itu sabar akan dapat menjauhkan menjauhkan diri dari perasaan cemas, gelisah dan frustasi, sebaliknya sabar akan mendatangkan ketentraman batin. Dengan bersabar manusia akan terdidik secara kejiwaan untuk memperkuat pribadi, serta menambah kemampuan untuk memikul kesulitan, menghadapi problematika hidup dan bencana dan musibah. Sabar juga dapat membangkitkan kemampuan untuk melanjutkan kehidupan yang lebih optimis (Tim Penyusun MUI,
2005: 23).

Umat Islam berdasarkan kitab suci yang dipercayainya mengajarkan bahwa musibah dan cobaan semua datang dari Allah yang tujuannya untuk menguji manusia. Semua musibah dan cobaan tersebut merupakan cara Allah untuk menguji manusia apakah ia sabar atau tidak menghadapinya. Sebagaimana terdapat dalam al-Quran misalnya QS. Al-Baqarah: 155157.

Kesabaran orang Aceh dalam menghadapi musibah dan bencana diperlihatkan oleh lbu MS, (55 tahun saat terjadi tsunami, seorang ibu rumah tangga yang selamat dari gulungan ombak tsunami). Ibu MS rumahnya hancur tidak tersisa, perabotan rumah habis terbawa tsunami, adik beberapa kemanakannya meninggal 6 orang di juga keluarga suaminya juga meninggal. Sebab bertepatan pada tanggal 26 Desember 2004 itu akan diadakan pesta pernikahan di rumah saudara suaminya di Lampaseh, malam ahad sebelum kejadian tsunami semua keluarga berkumpul di rumah tersebut dan meninggal karena tsunami. Anak Ibu MS, yang bernama Novi sakit karena banyak minum air tsunami pernapasannya terganggu dan paruparunya kotor. Novi dibawah ke Medan dan lbu MS dengan pesawat TNI Angkatan Udara dan dirawat secara intensif selama 44 hari di sana. Termasuk lbu MS juga dirawat meskipun tidak separah anaknya, Novi yang harus diinfus cairan puluhan botol. Setelah pulang dari Medan tidak mungkin kembali ke rumahnya Banda Aceh sebab kediamannya habis total, ia tinggal di Aceh Utara di tempat adiknya selama 1 bulan. Setelah itu, mereka tinggal di kamar sewa yang terbatas karena tidak banyak untuk menyewa rumah yang harganya melambung saat itu disebabkan banyak LSM dan NGO dari Jakarta atau luar negeri yang sudah datang ke Banda Aceh untuk melakukan rekonstruksi dan rehabilitasi pasca tsunami (Wawancara, 17 Oktober 2020).

Kesabaran Ibu MS tersebut patut dijadikan sebagai contoh sebab ia kehilangan rumah, perabot rumah, menumpang di rumah saudara, menyewa tempat tinggal sampai akhirnya kembali ke rumahnya semula di Lamdingin Banda Aceh.

\section{c. Tawakkal}

Tawakkal adalah berserah diri kepada Allah yang mengandung arti penerimaan sepenuhnya terhadap kenyataan diri dan hasil usahanya sebagimana adanya, atau dengan kata lain mau atau mampu menyesuaikan dengan diri dengan dirinya sendiri. Jika seseorang tidak mampu menerima keadaan sebagimana adanya, maka ia akan merasa tertekan, gelisah, cemas, dan takut bahkan lebih dari itu. Seseorang yang memiliki sikap tawakkal maka perasaan tertekan, gelisah, cemas dan takut akan hilang dari diri seseorang (Tim Penyusun MUI, 2005: 23).

Tu Bulqaini Tanjongan menguraikan bahwa nilainilai agama seperti tawakkal, ikhlas dan ridha kuncinya adalah aqidah, ketika seseorang memiliki aqidah yang kuat dan mantap dalam jiwanya, maka ia akan mampu meimplementasikan nilai-nilai tersebut dalam kehidupan sehari-sehari. Sebab dalam ilmu agama 
masyarakat Aceh nilai-nilai tersebut banyak dipelajari dalam tasawuf bahkan dipraktekkan di dayah (Wawancara, 23 September 2020).

Sikap tawakkal ini dapat dilihat dari pengakuan lbu MS. la dihempaskan tsunami dari kediamannnya di Gampong Lamdingin, Kecamatan Kuta Alam ke daerah Kerueng Cut, Tibang Kecamatan Syiah Kuala sekitar 5 $\mathrm{Km}$. Ibu MS awalnya berpegangan tangan dengan anaknya Novi selama beberapa jam, gelombang kedua datang dengan kuat anaknya lepas dari genggamannya. la kemudian bertawakkal sambil doa "Ya Allah selamatkan anakku, panjangkan umurnya dan pertemukan aku dengannya sebelum ia meninggal". Saat ia melihat gelombang besar dan seekor ular yang siap menerkamnya. Pada kondisi ia tidak berhenti berzikir, lailahaillalah, subhanallah, alfatiha, dan doadoa yang dia hafal. la mampu bertahan dari jam 9 sampai 4 sore di atas tumpukan kayu yang terbawa tsunami. Pada jam 4 sore setelah air mulai tenang ia diselamatkan perahu nelayan yang pulang dari laut. Di atas perahu sudah terbaring beberapa orang meninggal dan luka yang berat dan ringan, sekitar belasan orang (Wawancara, 17 Oktober 2020).

\section{d. Ikhlas}

Ikhlas dalam pengertian ini adalah suatu sikap seseorang yang mampu menerima musibah yang menimpa diri atau keluarganya tanpa keluh kesah, tanpa menyalahkan orang lain apalagi menyalahkan Tuhan. Ikhlas dalam berbuat adalah mengerjakan sesuatu tanpa pamrih, tanpa mengharapkan balasan, tetapi menerima apa saja dari Tuhan tanpa persoalan (Tim Penyusun MUI, 2005: 34-35).

Ikhlas juga berasal dari cerminan tauhid yang kuat. Tu Bulqani Tanjongan menjelaskan bahwa seorang korban tsunami dapat mengatakan, jangankan orang tua saya. Harta saya saja dapat diambil oleh Allah sebab saya adalah milik Allah. Prinsip untung saya masih selamat, untung anak saya masih selamat, jadi ketika terjadi musibah dari Allah, maka ia berprinsip untung, tidak pernah rugi. Jadi inilah nilai agama yang menjadi modal masyarakat Aceh dalam menghadapi bencana (Wawancara, 23 September 2020).

Bagaimana keikhlasan masyarakat Aceh dalam menerima bencana, Mursyid Djawas menjelaskan bahwa saya melihat dan berdialog langsung pada hari kejadian tsunami di Masjid Jami' Kopelma Darussalam Banda Aceh, ada seorang laki-laki yang kehilangan isteri dan 7 orang anaknya serta harta bendanya. Ketika saya bertanya bagaimana keadaannya dengan kehilangan orang-orang yang dikasihi dan harta bendanya, ia dengan tegar mengatakan jangankan istri, anak-anak dan harta, saya ini milik Allah, jika saya juga akan diambil oleh Allah, saya ikhlas dan rela (Wawancara, 24 Oktober 2020).

Teungku Rusli Daud, MA menjelaskan bahwa masyarakat Aceh banyak korban keluarga dan kehilangan harta benda tapi ia memiliki prinsip bahwa semua dari Allah dan akan kembali kepada Allah. Makamya ia dapat menerima kenyataan yang menimpa dirinya dan keluarganya. la akan menerima dan mengatakan bahwa sesungguhnya semua dari Allah dan akan kembali kepada Allah. Inna lillahi wa inna ilahi rajiun (Wawancara, 22 Oktober 2020).

Beberapa ungkapan tersebut di atas merupakan sikap keikhlasan seorang hamba kepada Allah. Seseorang yang telah sampai pada tahap ikhlas menerima cobaan, bencana sebagai takdir dari Allah maka secara psikologis, jiwanya akan lapang, hatinya rela menerima rasa kehilangan tersebut. Sebaliknya, seseorang yang tidak mampu menerima takdir, tidak ikhlas dengan kenyataan yang menimpanya, maka ia akan mereka kehilangan, ia akan stres depresi bahkan akan mengalami gangguan jiwa secara berkepanjangan.

\section{e. Kebersamaan}

Kebersamaan dalam terminologi sosial dapat disebut tolong menolong atau ta'wun. Menurut Teungku Rusli Daud, MA, bahwa tsunami datang mengingatkan kita agar kita saling menolong dan memiliki sifat kebersmaan. Sejak dahulu masyarakat Aceh suka menolong, dalam sejarah Aceh pernah memberikan bantuan kepada Turki dengan mengirimkan Lada sekaligus tanda persaudaraan dengan pusat ke Khalifahan Islam saat itu. Kemudian ketika Indonesia baru saja merdeka sangat membutuhkan bantuan masyarakat Aceh memberikan bantuan dua pesawat kepada Indonesia. Kemudian hampir semua daerah di Indonesia yang dilanda bencana pasti ada bantuan masyarakat Aceh seperti di Yogyakarta, Nusa Tenggara Barat dan Sulawesi Tengah. Di daerah ini terdapat masjid yang merupakan bantuan orang Aceh. Karena itu, masyarakat Aceh terkenal suka menolong (Wawancara, 22 September 2020).

Pada saat terjadi tsunami masyarakat Aceh yang tidak terdampak secara langsung memberikan pertolongan kepada korban tsunami, misalnya Nelayan dengan perahunya menolong lbu MS dan belasan orang lainnya yang terdampar di pantai selama seharian tidak makan dan minum. la kemudian diberi makan, minum bahkan pakaian setelah sampai di Peunayong (Wawancara, 17 Oktober 2020).

Masyarakat disekitar Tungkop, Lambaro Kafe, Sibreh, dan Aceh Besar yang tidak terdampak ikut membantu dalam bentuk, makanan, minuman, tempat tinggal kepada korban tsunami. Menurut Mursyid Djawas bahwa daerah-daerah tersebut merupakan daerah penyangga Banda Aceh baik secara logistik, geografis maupun demografis. Sehingga masyarakat yang menjadi korban bencana tidak ada yang kekurangan bahan makanan. Bahkan beberapa hari sesudah kejadian tsunami, masyarakat Aceh Tengah mengirimkan bantuan sayur mayur dan buah-buahan segar melalui mobil truk dan pick-up. Kebersamaan ini dilakukan para tokoh masyarakat Aceh seperti kepala desa, imam desa, tokoh adat yang merupakan elit sosial. Jadi ketika mereka yang turun tangan membantu korban bencana, masyarakat lainnya juga ikut tanpa diperintah. Ini juga merupakan modal sosial yang masih terlihat waktu tsunami terjadi. Solidaritas sosial dan ikatan sosial masih kuat (Wawancara, 24 Oktober 2020).

Nilai-nilai agama tersebut merupakan modal sosial 
yang sangat berharga pada manusia terutama dalam menghadapi bencana dan musibah yang secara tibatiba datang menimpa manusia. Jika manusia tidak memiliki sandaran nilai agama maka dapat dipastikan manusia akan stress, gila bahkan bunuh diri karena jiwanya tidak sanggup menerima kenyataan hidup yang pahit. Kehilangan orang-orang yang dicintai, harta benda bahkan masa depan serta cita-cita yang ia idamidamkan selama ini. Namun demikian masyarakat Aceh dengan kekuatan nilai-nilai agama mampu bertahan dan keluar dari kesedihan dan tekanan batin dan bangkit kembali.

\section{Sosialisasi Nilai Agama menjadi Modal Sosial}

Sosialisasi sering dimaknai sebagai suatu proses seseorang menghayati norma-norma kelompok di mana ia hidup sehingga timbullah diri yang unik. Sosialisasi modal sosial dapat dilakukan pada berbagai level seperti individu, keluarga, komunitas masyarakat bahkan negara (Amin, 2016: 138, Putri, 2017: 171).

Proses sosialisasi dari norma dan nilai agama dalam masyarakat sehingga menjadi modal sosial bukanlah pekerjaan mudah dan singkat. Menurut Tu Bulqaini Tanjongan bahwa sosialisasi tentang nilai-nilai agama kepada masyarakat sejak Islam pertama kali datang ke Aceh. Nilai-nilai ini secara cepat teraplikasi dengan ilmu sebab dengan ilmulah peradaban ini akan maju (bil ilmi hayatul Islam). Islam di Aceh juga maju karena ilmu tidak hanya ilmu agama, dahulu ulama Aceh berdasarkan manuskrip kitab-kitab karangan ulama zaman dahulu, mereka mampu merakit bom, dan beberapa ilmu lainnya tidak hanya ilmu agama (Wawancara, 23 September 2020).

Senada dengan itu, Teungku Rusli Daud, MA menjelaskan bahwa nilai-nilai agama ini disosiliasikan melalui pendidikan agama sejak kecil. Dahulu disetiap rumah masyarakat Aceh akan terdengar anak-anak yang belajar membaca al-Quran, kemudian ketika beranjak remaja akan belajar di bale dan meunasah. Kemudian sesudah itu ia masuk dayah untuk belajar ilmu-ilmu keislaman seperti tauhid, fikih dan akhlak (Wawancara, 22 Oktober 2020).

Mursyid Djawas menambahkan bahwa sosialisasi ini diawali dari Islam sebagai agama yang masuk dan dianut secara damai sejak abad ke-7 ada yang mengatakan abad ke-13. Karena agama ini telah mengkristal sepanjang ratusan abad lamanya maka ia telah menjadi karakter dan nilai yang berkelitkelindang dalam perilaku dan sikap hidup orang Aceh. Kita tahu bahwa dalam sejarah wilayah Aceh yang paling sulit ditaklukkan penjajah Belanda, panatisme agama menjadi spirit dan ruh yang mengobarkan semangat perlawanan. Nilai agama ini terus terpelihara dan tertransformasikan dalam masyarakat melalui lembagalembaga pendidikan seperti dayah, meunasah, masjid yang di dalamnya diajarkan ajaran-ajaran agama oleh para ulama (Wawancara, 24 Oktober 2020).

Tu Bulqaini Tanjongan mengatakan bahwa sampai saat ini masyarakat Aceh masih tetap memiliki landasan agama dan yang paling penting adalah emosi (fanatik) keagamaan, artinya sikap yang teguh memegang Islam dan rela mati demi Islam, ketika ada kelompok atau unsur dari luar yang akan membahayakan Islam, maka orang Aceh akan melawannya meskipun secara praktik ibadah orang tersebut tidak terlalu taat (Wawancara, 23 September 2020).

Sejalan dengan itu, menurut Sabri Arsyad, Kepala Bidang Perencanaan dan Kesiapsiagaan Bencana Kota Banda Aceh bahwa norma dan nilai-nilai agama ini juga disosialisasikan pada level gampong. Hampir semua gampong di Banda Aceh dibentuk Forum Pengurungan Resiko Bencana yang di dalamnya beranggotakan perangkat gampong termasuk tokoh agama pada tingkat lokal yaitu teungku imum gampong atau imam meunasah tentunya juga kepala desa dan tokoh masyarakat lainnya. Demikan juga ada Desa Tangguh Bencana (Destana), salah satu programnya Forum tersebut adalah edukasi dan penyadaran masyarakat akan ketahanan bencana, sadar bencana, membuat peta evakuasi, membuat jalur penyelamatan, simulasi penyelamatan gempa, menentukan titik kumpul (Wawancara, 23 Oktober 2020).

Tidak hanya pada level gampong lembagalembaga pendidikan mulai dari Sekolah Dasar sampai Perguruan Tinggi dan lembaga dan instansi pemerintah juga kita masuk untuk melakukan sosialisasi dan edukasi tentang ketahanan bencana. Tentu tidak fokus pada nilai-nilai agama tersebut, namun demikian secara umum kami sampaikan perlunya kesiapsiagaan bencana yang dapat membahayakan nyawa manusia (Wawancara, 23 Oktober 2020).

Bahkan ada beberapa meunasah yang di desain khusus ada tangga atau akses untuk penyelamatan diri dari bencana (Hasil observasi, 24 September 2020). Pemilihan meunasah dan masjid sebagai titik kumpul dan tempat penyelamatan diri merupakan pilihan yang tepat sebab secara sosial meunasah dan masjid merupakan pusat kegiatan sosial keagamaan juga tempat musyarawah, pendidikan dan kegiatan sosial keagamaan lainnya.

Dari pembahasan tersebut di atas dapat ditegaskan bahwa agama menjadi modal sosial dalam mewujudkan ketahanan bencana. Agama berupa kepercayaan yang terimplementasi dalam norma dan nilai yang terdapat dalam struktur dan tatanan sosial masyarakat. Dalam teori sosiologi bahwa agama dan norma serta nilai-nilainya mampu merekatkan dan mengitegrasikan masyarakat untuk bekerjasama untuk bertahan menghadapi bencana. Agama yang mengkristal menjadi aqidah sebagai norma dan nilainilai yang dianut dan dipratikkan oleh masyarakat ditambah dengan jaringan informal dari para ulama, tokoh agama sebagai elit sosial yang cukup dipatuhi oleh masyarakat melengkapi modal sosial tersebut. Sehingga dengan demikian masyarakat Aceh mampu bertahan dan keluar dari penderitaan akibat bencana gempa dan tsunami. 


\section{Kesimpulan}

A gama mampu menjadi modal sosial masyarakat Aceh dalam mewujudkan ketahanan bencana. Ketahanan ini disebabkan oleh adanya keyakinan agama yang kuat berupa aqidah dan tauhid yang tertanam secara dalam pada masyarakat Aceh. Ketahanan dalam arti mereka memiliki mitigasi dan persiapan yang kuat terhadap bencana sehingga terjadi pengurangan korban jiwa atau harta; adanya kelenturan struktur sosial jika bencana terjadi yang berfungsi dan berjalan sebagaimana mestinya; kecepatan pemulihan dalam arti upaya untuk kembali ke kondisi normal tidak memerlukan waktu yang cukup lama.

Norma dan nilai agama yang menjadi modal sosial dalam mewujudkan ketahanan bencana adalah tauhid, sabar, tawakkal, ikhlas dan kebersamaan. Meskipun nilai tauhid yang menjadi kunci dari semuanya, sebab tauhidlah yang akan melahirkan sifat sabar, tawakkal, ikhlas dan kebersamaan dan menolong sesama manusia.

Sosialisasi dari norma dan nilai agama dalam masyarakat sehingga menjadi modal sosial terjadi sejak Islam pertama kali datang ke Aceh. Karena nilai agama ini telah mengkristal sepanjang ratusan abad lamanya maka ia telah menjadi karakter dan nilai serta sikap hidup orang Aceh. Norma dan nilai ini terus disosialisasi dalam keluarga, masyarakat oleh tokoh agama melalui majelis taklim, pengajian, juga sosialisasi yang khusus kebencanaan oleh pemerintah seperti pada Forum Pengurangan Resiko Bencana pada level gampong.

\section{E. UCAPAN TERIMA KASIH}

$\mathrm{P}$ enulis mengucapkan terima kasih kepada pihak yang mendukung penelitian ini sehingga dapat terlaksana dengan baik. Rektorat dan seluruh jajarannya yang memberikan dukungan dana, Dekanat Fakultas IImu Sosial dan IImu Politik yang menfasilitasi, para dosen dan tenaga kependidikan di Universitas Malikussaleh, Aceh yang membantu penelitian ini. Demikian juga pihak-pihak yang menjadi informan di Kota Banda Aceh terima kasih yang tidak terhingga.

\section{DAFTAR PUSTAKA}

Amin, M. (2016). "Sosialisasi Nilai-Nilai Agama di Kalangan Mahasiswa Program Studi Sosiologi UIN Sunan Kalijaga." Sosiologi Agama: Jurnal Ilmu Sosiologi Agama dan Perubahan Sosial 10 (2): 133-154.

Alfian, I, (1987). Perang di Jalan Allah: Perang Aceh 1873-1912, Jakarta: Pustaka Sinar Harapan.

Badan Penanggulangan Bencana Nasional. 2016. Risiko Bencana Indonesia, Jakarta: Badan nasional Penanngulangan Bencana.

Darmi, T. (2016), "Optimalisasi Peran Perempuan Berbasis Modal Sosial Pada Sektor pemerintahan Desa (Study pada Pengelolaan Dana Desa)." Jurnal Antropologi: Isu-Isu Sosial Budaya 18 (1): 21-27.

Denzin, N. K., \& Lincoln, Y. S. (2009). Handbook of Qualitative Research, terj. Yogyakarta: Pustaka Pelajar.

Desfandi, M. (2014). "Urgensi kurikulum pendidikan kebencanaan berbasis kearifan lokal di Indonesia." SosioDidaktika: Social Science Education Journal 1(2): 191-198.

Duranti, A. (2012). Anthropology and linguistics. The SAGE handbook of social anthropology, 1: 12-26.

Fathy, R. 2019. "Modal Sosial: Konsep, Inklusivitas dan Pemberdayaan Masyarakat." Jurnal Pemikiran Sosiologi 6 (1): $1-17$

Fukuyama, F. (1995). Trust: The social virtues and the creation of prosperity (99). New York: Free press.

Kasim, M. F, Nurdin, A. (2016). "Resolusi Konflik Berbasis Kearifan Lokal di Aceh: Studi tentang Eksistensi dan Peran Lembaga Adat dalam Membangun Perdamaian di Kota Lhokseumawe." Jurnal IImu Ushuluddin 3 (1): 101-118.

Kasim, M. F. Nurdin, A. (2020). "Study of Sociological Law on Conflict Resolution Through Adat in Aceh Community According to Islamic Law." Samarah: Jurnal Hukum Keluarga dan Hukum Islam 4 (2): 375-397.

Marfai, M. A., Rahayu, E., \& Triyanti, A. (2018). Peran Kearifan Lokal Dan Modal Sosial Dalam Pengurangan Risiko Bencana Dan Pembangunan Pesisir, Yogyakarta: UGM Press.

Miles, M. B., \& Huberman, A. M. (1984). Qualitative data analysis: A sourcebook of new methods. In Qualitative data analysis: a sourcebook of new methods. Sage publications.

Moleong, L. J. (2019). Metodologi Penelitian Kualitatif.

Narayan, D., \& Cassidy, M. F. (2001). A Dimensional Approach to Measuring Social Capital: Development And Validation of A Social Capital Inventory. Current sociology, 49 (2): 59-102.

Nazir, M. 1985. Metode Penelitian, Jakarta: Ghalia Indonesia.

Nirzalin, Febriandi, Y. (2020). "Teungku Dayah Agency and Religious Social Capital on Drug Eradication In Aceh, Indonesia." Jurnal IImu Sosial IImu Politik, 23 (3): 210-222.

Paramita, I. G. A. (2018). "Bencana, Agama dan Kearifan Lokal." Dharmasmrti: Jurnal IImu Agama dan Kebudayaan, 18(1): 36-44.

Putnam. (2004). Social Capital and Civic Community, USA: Infed. 
Putri, Z. E., Azwar (2020). "Modal Sosial kelompok Rentan Sebagai Upaya Disaster Risk Reduction," Jurnal Antropologi: Isu-Isu Sosial Budaya 22 (2): 236-245.

Putri, I. A. (2017). "Jaringan Kekerabatan Matrilineal Sebagai Modal Sosial Perempuan Caleg dalam Pemilu 2014." Jurnal Antropologi: Isu-Isu Sosial Budaya 19 (2): 167-178.

Ritzer, G. dan Goodman D.J., (2004). Teori Sosiologi Moden, Edisi Keenam, Terjemahan, Jakarta: Kencana.

Sari, R. H., \& Taqwaddin Husin, S. (2016). "Kearifan Lokal Smong Masyarakat Simeulue Dalam Kesiapsiagaan Bencana 12 Tahun Pasca Tsunami." Jurnal Ilmu Kebencanaan: Program Pascasarjana Unsyiah, 3 (1): 27-32.

Sukmana, E. T. 2013. "Revitalisasi Keharmonisan Dunia (Menilik Relevansi Antara Moral, Agama, dan Bencana)." Jurnal Essensial, Vol. XIV No. 1 April.

Suwignyo, A. (2019). A Tsunami-Related Life History of Survivors in Banda Aceh, Indonesia and Sendai, Japan. Jurnal IImu Sosial dan IImu Politik 23(2): 120-134.

UNISDR, (2004). Global Assessment Report on Disaster Risk Reduction: Revealing Risk, Redefining Development, Information, Press, UK: Oxfrod.

UNISDR, (2004). Living with Risk: A Global Review of Disaster Reduction Initiatives, Inter-Agency Secretariat of the Internasional Strategy for Disaster Reduction (UNISDR).

Utami, S. N. H. (2012). Bertani Selaras Alam di Lereng Merapi:is: Kekuatan Agama dan Kearifan Lokal dalam Proses Kebangkitan Pasca Gempa di Kasongan Bantul, Yogyakarta dalam Agus Indiyanto danisepirqom Kuswanjono, Konstruksi Masyarakat Tangguh Bencana Kajian Integratif IImu, Agama, dan Budaya, Buku III, Yogyakarta: Universitas Gajah Mada, 2012.

Wawancara dengan Dr. Mursyid Djawas, Dosen Universitas Islam negeri Ar-Raniry Banda Aceh, 24 Oktober 2020.

Wawancara dengan NA salah seorang warga yang selamat dari gempa dan tsunami di Masjid Raya Baiturrahman, 16 Oktober 2020.

Wawancara dengan Sabri Arsyad, Kepala Bidang Perencanaan dan Kesiapsiagaan Bencana BPBD Kota Banda Aceh, 23 September 2020.

Wawancara dengan Teungku Rusli Daud, MA, Anggota Majelis Permusyaratan Ulama dan Ketua Nahdlatul Ulama Kota Banda Aceh, 22 Oktober 2020.

Wawancara dengan Tu Bulqaini Tanjongan, Wakil Ketua Majelis Permusyaratan Ulama Kota Banda Aceh, 23 September 2020.

Wawancara dengan Yubahri, Sekretaris BPBD Kota Banda Aceh, 23 September 2020.

Wawancara lbu MS, seorang warga yang selamat dari gempa dan tsunami di Kota Banda Aceh, 17 Oktober 2020.

Zal, W. A. (2018). "Ketahanan Komuniti Mangsa Bencana Banjir Di Pantai Timur Semenanjung Malaysia Dalam Konteks Modal Komuniti." Journal of Nusantara Studies (JONUS), 3(2): 41-53. 